\title{
A study on the effects of banks' cash management on their share value
}

\author{
Syed Behzad Zakaria*
}

Department of Financial Management, Farabi Campus Faculty, University of Tehran, Tehran, Iran

\begin{tabular}{|c|c|}
\hline CHRON I C LE & ABST RACT \\
\hline $\begin{array}{l}\text { Article history: } \\
\text { Received January 20,2014 } \\
\text { Accepted 5 July 2014 } \\
\text { Available online } \\
\text { August } 112014 \\
\text { Keywords: } \\
\text { Stock value } \\
\text { Cash management } \\
\text { Econometric } \\
\text { Ordinary least-squares }\end{array}$ & $\begin{array}{l}\text { Banking industry, which is closely associated with the invention and spread of the money, } \\
\text { influences on economic growth and development. The main role of the banking system is to } \\
\text { create a saving of deposits and using it in beneficial investments or lending it to different } \\
\text { people with various investment purposes. Accordingly, banks play essential role as financial } \\
\text { intermediaries and provide necessary funds from investors to borrowers and users . } \\
\text { In this regard, appropriate management of cash flows is essential for banks. Cash management } \\
\text { is a trade-off between risk and return like what happens in other kinds of managements } \\
\text { meaning that improving cash management increases the cash considering the limited amount of } \\
\text { resources and eventually increases the share of the financial institution. In this paper, the impact } \\
\text { of cash management in Iranian banks on their value of stock in } 2011 \text { was examined based on } \\
\text { the econometrics model and least-square technique. The results indicate a significant and } \\
\text { positive impact of the increase in the cash management index on the banks' stock value, } \\
\text { meaning that a one percent increase in this index will increase } 1.1 \text { percent of the banks' stock } \\
\text { value. }\end{array}$ \\
\hline
\end{tabular}

\section{Introduction}

Today, banks play a significant role in financing commercial businesses. They facilitate trades by organizing receipts and payments and this way develop the markets on one side and lead micro and macro savings towards the commercial businesses and economic activities on the other side. Hence, banks provide economic growth and development this way. Banks are subject to different challenges such as cash management as one of the most important of them (Fabozzi, 2005). In case of banks, cash management refers to predicting and providing required liquidity with lowest possible expenses (Fabozzi, 2005). The main reason for cash management is to provide banks with resources obtained from short-term and micro deposits while investment facilitation is executed on assets with low degree of liquidity. Therefore, the primary objective of banks is to provide a balance between short term financial obligations and long term investments. If an insufficient amount of liquidity is kept up for this, banks will be at risk of lack of capability to fulfil obligations and eventually go bankrupt. On

*Corresponding author

E-mail addresses: b.zakariaa@gmail.com (S. B. Zakaria) 
the other side, excessive amount of liquidity will lead to inefficient allocation of resources, reduction in the efficiency ratio and consequent loss of the market.

When liquidity analysis is investigated, cash flow data is far more reliable than the balance sheet information. Balance sheet data and information are stationary and indicate the statutes of a business at a specific period of time, whereas cash flow statement indicates changes in financial statements. Cash management is important in terms of firms with financial activities, considering increasing changes and competitions in societies today. Financial managers' ability to understand and to respond properly and quickly to the market status and its changes is an advantage for financial institutions. Therefore, such managers should be aware of various characteristics of the institutional activities including cash management as the most important of them. Managers should also provide financial reports based on financial recorded information, return and cash management (Arabmazar \& Ghanbari, 1997).

Insufficient liquidity is associated with the institution's lack of capability of fulfilling its financial obligations. This can lead to forced sales of assets and in extreme cases can lead to bankruptcy of the financial institution. Therefore, financial managers have realized that company liquidity ratios including current ratios, net working capital and so forth are important in order to determine the sufficient amount of cash capital for fulfilling the obligations (Wang, 2002).

Cash management is one of the important aspects of financial management that has attracted much attention among financial managers. In this regard, lack of liquidity makes banks incapable of fulfilling their obligations in due time and thus incur excess costs. Cash management may seem rather basic and simple, however success and reputation of a financial institution or a bank depends on an effective cash management. In fact, a bank receiving a great deal of cash resources, without any investment will virtually end up bringing in no revenue. In other words, it will not be able to increase its assets and liquidity and perhaps also face the risk of bankruptcy (Chen, 2005).

In summary, cash management is a trade-off between risk and return as other kinds of managements as keeping excessive cash in central bank accounts, other banks and legal reserve will result in risk reduction and at the same time eliminates opportunities for banks to invest and thus decreases their return. Since liquidity is part of the balance sheet, cash management will be accompanied with other decisions concerning the balance sheet such as maximizing the stock value. Since return on assets and stock value are the results of banks' efficiency and their ability to exploit by means of cash management, this research seeks to examine the relationship between cash management and the stock market value in Iranian banks.

Until 1970, most bank's activities comprised credit payments containing intermediation between small and low-cost deposits and lending. Pricings and investments were based on simple decisions and the most significant challenge of the management was the quality control of the assets, losses on loans and overhead costs. Emerging inflation problems, economic recession and instability of interest rates in the late 1970s and early 1980s, made assets and liabilities management vital for maintaining the acceptable profit margin (Fabozzi, 2005).

Committee on Banking Supervision at the Bank for International Settlements called Basel believe that bank liquidity is very importance and its deficiency may create wide consequences. Therefore, this committee has performed extensive researches in order to reach a set of principles and practices in terms of cash management. After necessary changes and modifications on a report entitled "a framework for measuring and cash management" released in September 1992, this committee resealed a magazine entitled effective methods for cash management in banks in February 2000.

One of the significant characteristics of banks is their high capacity of liquidity. When the amount of assets with high liquidity is reduced, the bank is encountered with liquidity risk, meaning that it will be unable to pay its debts at maturity. Hampton identifies daily trade needs, unexpected needs and cash in certain conditions as the reasons banks maintain liquidity. 
Different levels of liquidity in regard to accounting theory are defined below:

Liquidity: is the relative ability of the profit unit to convert assets into cash or near-cash assets.

Solvency: is the ability of the profit unit to gain cash for paying debts at maturity. The solvency makes it possible for a bank to survive and insolvency may lead to suspension, bankruptcy or the bank liquidation.

Financial flexibility: is the ability of the profit unit to provide cash in a short time from the time of receiving the information

Liquidity, solvency and financial flexibility are three levels of cash management in which the composition and structure of the balance sheet directly influence. The financial flexibility is a concept wider than the solvency and the solvency is likewise wider than liquidity (Soori \& Vesal, 1999).

According to what was said, appropriate cash management in banks will lead to more profitable banks and thereby increases their value of the stock. Therefore, varoous studies have been carried out in terms of cash management outcomes. Some of these studies are mentioned as follows:

Some people believe that companies with low rate of cash flow often yield better results. They state that low rate of cash flow helps managers minimize keeping non-profitable assets and try to maintain the debt capacity of the company. The positive effect of the low rate cash flow on the net future cash flow of the company assets is another finding of this study.

Walker and Robinson (1994) in a study showed that unlike the operating cash flow, the profit prior to unexpected items and operating working capital were individually important in explaining the changes in current ratio. Furthermore, measuring additional information about the accounting variables indicated that the profit prior to unexpected items and the operating working capital could explain well the changes in the current ratio, while operating cash flow did not provide any additional data regarding the current ratio.

Bowen et al. (1987) examined the role of cash and accrual flow data in decisions made by fiscal statements users in terms of various perspectives. The results suggested that profits provided more explanation ability than cash flow variables and accrual accounting likewise provided more explanation ability than cash flow. Bakhtiari (2006) in an article entitled effective methods of cash management in banks, first remarked required principles for establishing cash management in banks and then addressed the characteristics of liquid assets and liabilities.

Soleimani (2007) in a study entitled organizational infrastructure necessary for cash management in Islamic banking, first addressed cash management challenges and then addressing the institutional infrastructures of cash management, he had a review on several experiences of Islamic countries in this area.

There are also some studies, which examined the relationship between assets and stock return and cash management in a work entitled the relationship between assets and stock return and cash management. The results indicated that there was a significant relationship between return on assets and cash management in large and small companies and there was also a significant relationship between stock return and cash management in small and large companies.

\section{The proposed method}

The present study examines the impact of cash management in banks on their stock market value by means of statistical and econometric models. Therefore, it is necessary to introduce the model and the technics used to estimate such impact. The main hypothesis of this research is to study the positive impact of the cash management on the stock market value. Therefore, statistics and information regarding 72 Iranian banks available in central bank of Iran were gathered. Also cash conversion cycle (CCC) equation was used to estimate the cash management index using Eq. (1) as follows, 
where in Eq. (1), the inventory conversion period (ICP) is added to the receivable conversion period (RCP) and then the payable deferral period (PDP) is deducted from it to calculate the cash conversion cycle (CCC). The calculated variable represents cash management and the lower it is the more efficient will be the cash management (Wang, 2002). Other variables of this equation are calculated as follows: the inventory conversion period is calculated by dividing the average inventory by the average price during a year and the receivable conversion period is calculated by dividing the average accounts receivable by the average sale during a year and the payable deferral period is calculated by dividing the accounts payable by the actual cost. As mentioned earlier, in this study, the population of this survey includes all banks licensed by the Central Bank of the Islamic Republic of Iran. Therefore, sampling method was the complete sampling and includes all members of statistical population during the year 2011. All information has been extracted from official reported from Tehran Stock Exchange and investigated banks' financial statements. Statistical methods of this study is to estimate the effect of liquidity management on the value of stock market pattern of ordinary least squares (OLS) based on econometric method. Econometrics is dealing with systematic study of economic phenomena using observed data (Arrow, 1960). Although many econometric methods express the application of statistical models, some specific characteristics of economic data are associated with the nature of domestic circumstances. Economic data are generally observational, and didn't obtain from controlled tests. Since economic units operate with each other, the observed data show a complex economic equilibrium and they are not derived from a simple act of communication caused by precedence or technology. In this study, simple linear regression is used as follows.

$Y_{i}=\beta_{0}+\beta_{1} x_{i}+\varepsilon_{i}$

where $Y_{i}$ represents the value of bank shares, $x_{i}$ is also the calculated index of liquidity management and $\beta_{i}, i=0,1$ are the coefficients estimated by the technique of least squares (OLS). It is easily seen by examining the regression models that any improvement in regression analysis depends on a better understanding of such disruptive $\varepsilon_{i}$ within the model. When we try to understand and measure some components of disruption phrase, the known components of the model are placed in certain part and set of passive factors that remain will constitute the disruption phrase. So, disruption phrase is not visible and measurable. So the only way out of this theoretical dilemma is designing set of reasonable assumptions about disruption phrase to continue regression analysis. In linear regression models, OLS is the simplest method. The results of the implementation of OLS technique is summarized as follows,

$\begin{array}{lccl}Y_{i}= & 0.475822+1.106941 x_{i} & \\ \text { t-value } & 10.94398 & 16.08720 & \text { Durbin-Watson }=1.98 \\ \text { Sig. } & 0.0006 & 0.0000 & \bar{R}^{2}=0.908386\end{array}$

As we can see from the results of Eq. (2), the coefficient of independent variable is statistically significant. The adjusted R-Square indicates that the independent variable can describe $91 \%$ of the changes on dependent variable. In other words, one percent increase in bank's liquidity management will lead to $1.1 \%$ increase in stock value. In addition, Durbin-Watson value is equal to 2, which means there is no autocorrelation among residuals. In statistics, the Jarque-Bera test is a goodness-offit test of whether or not sample data have the skewness and kurtosis matching a normal distribution. Fig. 1 demonstrates the results of our survey and we can confirm the normality of the independent variable. 


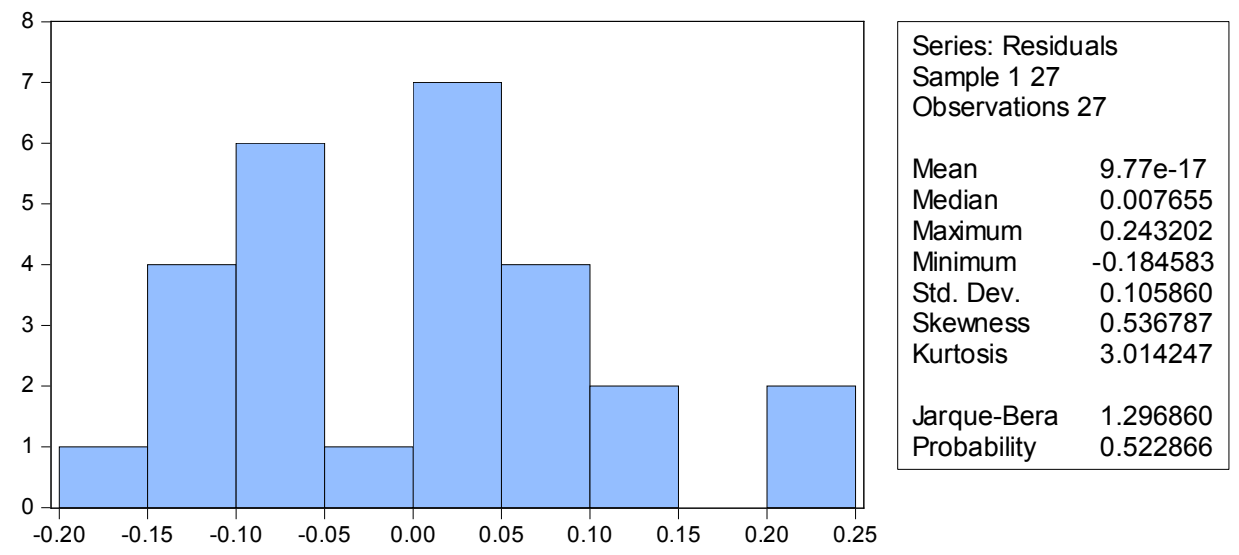

Fig. 1. The results of Jarque-Bera test

Next, the Breusch-Godfrey-Bertolo test is applied to evaluate the validity of some of the modelling assumptions inherent in applying regression-like models to observed data series. More specifically, it examines for the presence of serial dependence that has not been included in a proposed model structure and which, if exists, it means that incorrect conclusions is drawn from other tests, or that sub-optimal estimates of model parameters are obtained if it is not considered. The results of Breusch-Godfrey-Bertolo test is summarized in Table 1 as follows,

Table 1

The results of Breusch-Godfrey-Bertolo test

\begin{tabular}{lccc}
\hline F-statistic & Prob. F(2,23) & Obs*R-Squared & Prob. Chi-Square (2) \\
\hline 0.057933 & 0.9439 & 0.135334 & 0.9344 \\
\hline
\end{tabular}

According to the results of Table 1, we can confirm that there is no serial dependence. Finally Table 2 demonstrates the results of Glejser test (Glejser, 1969).

Table 2

The results of Glejser test

\begin{tabular}{cccccc}
\hline F-statistic & Prob. F(1,25) & Obs*R-Squared & Prob. Chi-Square (1) & Scaled explained SS & Prob. Chi-Square (1) \\
\hline 0.187578 & 0.6687 & 0.201076 & 0.6539 & 0.178709 & 0.6525
\end{tabular}

The result of Glejser test indicates that there is no heteroskedasticity effect and therefore, the results of regression analysis is valid.

\section{Conclusion}

Liquidity management is especially important in banks. Like many other managerial decisions, this management is a kind of confrontational between risk and efficiency, managing the liquidity is in conjunction with other decisions of balance sheet and it is considered as one of main items of bank's expenditures. In fact, maximizing the efficiency of this investment in this area is directly related to cost minimization. The purpose of this study was to examine the impact of liquidity management on the value of banks' stock price. The results show that liquidity management will enhance the value of banks' shares. In our survey, a 1\% increase in liquidity management index will lead to $1.1 \%$ increase in the value of bank shares. Accordingly, banks must have accurate recognition of their main cash flows for practical and accurate liquidity management and exactly identify controllable cash flows. After identifying main cash flows, banks must implement a system to their financial programming.

\section{Acknowledgment}

The authors would like to thank the anonymous referees for constructive comments on earlier version of this paper. 


\section{References}

Arabmazar, A., \& Ghanbari, H. (1997). Liquidity management Theoretical Foundations at banks. Proceedings of the Eighth Conference on Islamic Banking, Tehran, Banking Institute, 127-151.

Arrow, K. J. (1960). The work of Ragnar Frisch, econometrician. Econometrica: Journal of the Econometric Society, 28, 175-192.

Bakhtiari, H. (2006). Effective methods of liquidity management at banks. Auditor, 34, 94-86.

Bowen, R. M., Burgstahler, D., \& Daley, L. A. (1987). The incremental information content of accrual versus cash flows. Accounting Review, 62(4), 723-747.

Chen, G. (2005). The audit opinions of earnings management in listed companies of China. Journal of Modern Accounting and Auditing, 1(7), 67-81.

Fabozzi, F. J. (2005). The handbook of fixed income securities (Vol. 6). New York: McGraw-Hill.

Frieden, J. A. (1991). Invested interests: the politics of national economic policies in a world of global finance. International Organization, 45(04), 425-451.

Glejser, H. (1969). A new test for heteroscedasticity. Journal of the American Statistical Association, 64(325), 316-323.

Imbierowicz, B., \& Rauch, C. (2014). The relationship between liquidity risk and credit risk in banks. Journal of Banking \& Finance, 40, 242-256.

Lei, A. C., \& Song, Z. (2013). Liquidity creation and bank capital structure in China. Global Finance Journal, 24(3), 188-202.

Lucchetta, M. (2007). What do data say about monetary policy, bank liquidity and bank risk taking?. Economic Notes, 36(2), 189-203.

Soleimani, M. (2007). Required organizational Infrastructures for liquidity management at Islamic Banking. The first Islamic conference, Tehran, Imam Sadegh University, 147-163.

Soori, D., \& Vesal, M. (1999) New methods of financing and liquidity management in banks. Proceedings of the Nineteenth Conference on Islamic Banking, Tehran Banking Institute, 231-247.

Wang, Y. J. (2002). Liquidity management, operating performance, and corporate value: evidence from Japan and Taiwan. Journal of Multinational Financial Management, 12(2), 159-169.

Walker, R. G., \& Robinson, S. P. (1994). Competing regulatory agencies with conflicting agendas: Setting standards for cash flow reporting in Australia. Abacus, 30(2), 119-139. 